\title{
From under the shadows: developing awareness in a conventional market with a product less recognized
}

This article was published in the following Dove Press journal:

International Journal of Wine Research

29 July 2010

Number of times this article has been viewed

\author{
Nelson Barber \\ Janis Donovan \\ Whittemore School of Business, \\ University of New Hampshire, \\ Durham, NH, USA
}

Correspondence: Nelson Barber Whittemore School of Business, University of New Hampshire,

Durham, NH, USA

Tel + I-603 $862357 \mid$

Email nelsonbarber@msn.com

\begin{abstract}
The wine industry has considered product quality as the benchmark driving competitiveness, with wine quality the target standard. This focus on quality exposes producers to intense price competition with consumers alternating between wines. Some research has been done on country of origin suggesting the value consumers place on specific origins goes deeper than quality and price, inferring the presence of other dimensions such as emotional, economic, and social associations. However, little has been done to determine the value consumers place on the sub-wine regions of these larger countries. This study examines dimensions of wine region brand equity, by analyzing benefits sought by consumers. Data was collected through a survey conducted in the United States which identified drivers of preferences for wine regions and relationships that may exist between those drivers and wine region preferences. The findings suggest brand equity of small wine regions results from consumer motivational factors and these factors are determinants of consumer preferences. Linking these factors to consumer, demographic and location allows for direct marketing strategies.
\end{abstract}

Keywords: wine region brand equity, consumer, gender, millennial

\section{Introduction}

Meeting conventional market driven consumer demand is the most cost-effective way to succeed in business and marketing managers are keenly aware of this issue. Yet, wine produced in sub-regions overshadowed by a larger country or state of origin or even located next to a well-known region is often overlooked and not considered mainstream. There is some discussion whether wines produced in these sub-regions can ever become "conventional" and be considered as seriously as the larger country, state or popular regions suggesting that strong marketing leadership is needed. ${ }^{2-4}$ Thus, it has been acknowledged effective marketing communications need to recognize the relationship between a product (brand) and the consumption values or benefits consumers' seek. ${ }^{1-6}$ Marketing managers are likely to question what truly motivates consumer preference in terms of brand benefits. The variability of consumer segments and purchase criteria are important to understand when matching brands to markets. ${ }^{2,5}$

The market place can be overwhelming for wine consumers, especially given the globalization of wine markets, resulting in consumers being offered a larger number of brands than ever before. ${ }^{3}$ This increase in available wine brands suggests there is growing importance of brand equity in the wine industry. The wine industry has looked to product quality as the key for preserving competitiveness but consumers easily find substitute wines when the sole message is one of quality, resulting in fierce price competition. This is in complete contrast to a common viewpoint that a 
significant amount of a wine's charm is acquired through its terrior. ${ }^{2}$ Yet, little has been done to determine the value consumers place on different wine locations, particularly regions of countries of origin, with respect to factors other than quality and price. . $^{2,3}$

The choice of which wine origin benefits to communicate would seem to be especially important in situations where consumers may vary widely in the benefits sought, are less familiar with brand names, and evaluate origins rather than products. $^{2}$ Considering that effective marketing must recognize the relationship between a brand and the benefits consumers seek, ${ }^{5}$ the question is how to conceptualize, measure and utilize consumer perceptions of wine locations and the value placed on attributes such as emotions, social acceptance and the environment in relation to those locations.

Previous research by Orth et al examined wine producing countries (eg, California, France, Italy), ${ }^{2}$ rather than specific sub-regions. To explore these issues further it is necessary (1) to gain a better understanding of consumer perceptions of the dimensions of sub-region wine identity or brand recognition (2) to determine if perceptions of these sub-regions are similar to perceptions of other sub-regional wine regions and (3) to segment consumers by demographics and compare to regional preferences for the purpose of developing market strategies. Using developed hypotheses, this current study will test the three points discussed above using a consumer sample across different regions of the United States. ${ }^{2}$ This research should add value to wine marketing efforts on the dimensions of wine region benefits by considering the relationship of consumer preferences and location where respondents live. The results are also expected to provide evidence that wine regions should not rely on the brand image of the larger country or state of origin in which it is located and that they need to establish their own unique brand identity.

\section{Literature review}

Branding is the means used to differentiate one product from another. ${ }^{2,3,6-9}$ Mowle and Merrilees suggested a brand is essentially a particular product, place or service enhanced such that potential consumers perceive relevant, unique, sustainable values matching their needs most closely, ${ }^{5}$ thus highlighting the added values consumers perceive intrinsic in a brand. These added values can be separated into two distinct concepts. The first is the functional value and the other is the symbolic value. ${ }^{8}$ Functional values communicate the products benefits that satisfy consumer's needs, while symbolic values connect the brand to the emotional values, such as intangible feelings and symbolic benefits satisfying the consumer's self-expression needs. ${ }^{4,8}$ Mowle and Merrilees suggested that symbolic values as a form of differentiation are more sustainable than functional values and symbolic values can send social signals to consumers. ${ }^{5}$

\section{Brand benefits and choice}

To predict brand selection researchers in marketing have generally focused on the relationship between the consumer and the product. ${ }^{3}$ However, researchers by and large did not distinguish between the effect caused by a brand name and the effect originating from the product with regards to attribute level combinations. Recently, research has put forth the concept that the product in addition to the brand name, is able to contribute or offer varying forms of benefits to the consumer. ${ }^{4,5}$ In the work by Orth, it was suggested that consumer-perceived or desired brand benefits could be classified according to a number of basic dimensions, ${ }^{10}$ with six distinct dimensions emerging, for the use of multiple item scales. These dimensions are quality/functional, price/ value, social, emotional, environmental and health benefits. Testing of these scales to branded consumer goods have suggested the basic dimensions are suitable for assessing brand images and predicting consumer preferences. ${ }^{7}$ There are a few studies that have measured consumer prediction choice, which is of considerable interest to marketing managers more so than perceptions, intentions or attitudes. Orth created the model to demonstrate the benefit dimensions. ${ }^{10}$ The model considered the influence on brand and choice of attributes which included Price (value), Functional (performance), Social (self-concept), Environmental, Emotional, and health benefits.

\section{Origin effect}

The significance of a regional brand feature compared to other wine-buying factors is a critical question to consider with the results depending on the comparative strength of the regional brand versus a producer's own brand. The regional brand is especially important to new wineries as they need time to develop a strong producer and product image perception among consumers. It has been noted that consumers rely on external cues such as brand name or country of origin when evaluating a product's quality. ${ }^{11}$ When considering wine product brands the relative brand strength of wine regions understandably differ, moreover they occur in a hierarchical order. For example, when considering Argentina, the Mendoza Valley has secured the top position and is most recognized as a quality wine region. Thus the struggle for the remaining market positions 
within consumer's minds rages on. Other research studies that have investigated antecedents of country-of-origin assessment, ${ }^{2,4,12-14}$ including consumer's perceptions and inferences of products from a given place of origin, $2,4,14,15$ suggest country of origin is not limited to product quality signals, but rather linked to emotions, identity and pride, thus transforming the country of origin into an "image" attribute. $^{2}$ This image attribute can be an important determinant of consumer preferences and an important source of brand equity. ${ }^{15}$ Strategies for marketing country of origin have been expanded to concentrate on specific geographic states or regions demonstrating how origin effects can complement the importance of price, brand name or other product attributes in determining preferences. ${ }^{2,4,15}$

Research also supports the concept that consumers rely on the origin of a product to infer its quality, and support from these studies suggest there is too much focus on cognitive consumer processing and not enough on the emotional aspect of consumer decision making., ${ }^{4,15}$ Pharr and Verlegh and Steenkamp demonstrated, through two meta-analyses on origin effects, ${ }^{15,16}$ that analysis of emotional processes by consumers are regularly overlooked. They surmised that emotions consumers associate with product origins are more influential to product selection than the quality aspects generated through consumer intellectual reasoning.

The wine industry views the quality of their products as critical to maintaining and increasing their competitive edge resulting in fierce price competition since consumers find it easier to move from one brand to another if the message is solely directed toward quality. ${ }^{2}$ Thus effective marketing communication needs to recognize the relationship between a brand and the consumption benefits consumers seek. ${ }^{2,4,15}$ The question then becomes how consumer's perceptions of wine origins, as reflected in dimensions such as emotions, social acceptance, or environmental, can be measured and developed.

Working from previous studies using benefits categorized into the basic dimensions of function, social, price, and emotion, ${ }^{2,15,17,18}$ this current study used the PERVAL measurement instrument for benefits obtained by consumers assessing wine regions as a brand using these basic dimensions.

\section{Dimensions of wine region equity}

It has become accepted that countries or regions are viewed like brands and the value of branding them has become clearer. ${ }^{2-4}$ Wine marketers started to understand how equity can be added to their brands through the careful influence of their particular origin. ${ }^{2,3}$ Such is the case with pinot noir, where consumers are likely to express different purchase behaviors toward Oregon, Burgundy, France, and Hawkes Bay, New Zealand, all areas producing quality pinot noir based wines. For example, a study of quality wine consumers in the United States discovered information on the wine label linking a place and product to be the critical source of information sought by wine consumers. ${ }^{19}$

The literature recognizes that brand equity is composed of brand association, brand perceived value, brand awareness, and brand loyalty, ${ }^{4,20}$ and when applying these concepts to wine marketing, the dimensions of wine region equity should be considered. ${ }^{2}$ As stated earlier, Orth and tested by Orth et al there are six dimensions of wine region equity that should be considered as drivers of consumer preference. ${ }^{2,6}$ These dimensions were functional, price, social, emotional, environmental benefits and health. However, Orth et al tested them only on a broad view by assessing an entire wine producing country's equity, such as France or Italy, rather than on specific sub-regions or appellations within these countries, such as Loire, France or Chianti, Italy. Therefore, based on the research discussed above, the first proposed research hypothesis, as modified from Orth et al is: ${ }^{2}$

Hypothesis 1. Wine preferences for varied sub-wine regions differ significantly with respect to the benefits consumers seek regarding the five dimensions of wine region equity.

\section{Consumer demographics}

Satisfying consumers and understanding their needs is the basis of marketing theory, particularly because customers have different needs, and rarely is it possible to satisfy all customers by treating them the same. To assure these different needs are met, market segmentation involves separating consumers into internal homogeneous categories that are likely to use or buy similar products or services and react similarly to marketing efforts.

Gender continues to be one of the most common forms of segmentation used by marketers and advertisers, with men and women likely to differ in information processes and decision making. This is true because globally, women are the ones who make the daily purchasing choices and are responsible for the everyday shopping for their households. The processes underlying the judgment of men and women regarding consumption, information processing, ${ }^{20}$ and decision making ${ }^{21}$ have been found to be important considerations. The research literature seems consistent in ascribing specific personality traits to men and women and in suggesting that the unique interests and knowledge associated with the social roles of gender can also guide 
their judgments. In general, men are reported to be more independent, confident, competitive, willing to take risks and less prone to perceive product risk than women who rely more on instincts. ${ }^{20}$ On the other hand, self-image and social risk factors are gender specific. In a study by Hall et al they found that men rate their feelings of social and psychological values higher than women in relation to the perceived value of purchasing and consuming a product; and that men have a stronger motivating trait to impress others than women. ${ }^{22}$ This social acceptance factor was suggested in a recent US study. ${ }^{19}$ When it came to making a wine purchase decision, men were less likely to ask a family member/friend for assistance with the wine purchase compared with female respondents, suggesting that their vulnerability of feelings and concern for social acceptance may be real.

As for generational differences, a real problem for consumer product manufacturers, which includes wine and wine products, is that Baby Boomers are not an expanding market resource. ${ }^{23}$

\section{Millennial generation}

The millennial market segment in the United States is estimated to be 76 million and between the ages of seven and 29. This generational cohort is considered by most major consumer product companies as a generation with very high buying power. ${ }^{24}$ This generation has grown up in a mediasaturated, brand conscious world and has a lot of discretionary income and influence over family purchases as evidenced by the use of parent co-signed credit. ${ }^{24}$

\section{Generation $X$ generation}

This generation, born between 1965 and 1976 and over 55 million strong, witnessed great social, economic and environmental changes as they grew up, resulting in expectations of change, even embracing it, viewing anything that does not change with suspicion. ${ }^{24}$ Economically, they witnessed falling wages, shrinking benefits, and growing economic inequality. Style-conscious but seldom affluent, they maintain their inherent suspicion of marketing and media campaigns even as they embrace products and services that answer their iconoclastic, resolutely youthful tastes and needs. ${ }^{24}$

This current study will focus on two demographic cohorts in the United States; the Millennial and the Generation X generations. These cohorts were chosen primarily because this research is interested in the Millennial generation, the largest and youngest generational cohort and Generation $\mathrm{X}$ because they are in the immediate wake of the Baby Boomers.
Hypothesis 2. Consumer demographics of gender and age differ significantly with respect to the benefits sought in the dimension of wine region brand equity.

\section{Methodology \\ Design of study}

Developing a survey based approach, Park and Srinivasan in their study of measuring and understanding brand equity suggested that by estimating brand equity at the individual level as opposed to the aggregate or segment level, marketing managers can aggregate the individual-level measures to quantify both the mean and standard deviation of brand equity for any segment of interest. ${ }^{6}$ Thus, to undertake testing the two hypothesis presented in this study, it was decided to use a modified version of surveys conducted by Orth et al and Dodd and Bigotte as the results of the survey would indicate if consumers have similar perceptions and reasons for choosing wine produced in sub-regions. This study considered the general adult population of the United States for its sample, randomly selecting them from an e-mail data base maintained by a national data warehouse company ("Organization"). A profile was created, so that respondents to be considered in the final data analysis that required them to be over 21 years of age, which is the legal drinking age in the United States, considered themselves to be wine consumers, and to have purchased a wine in the past year. If any respondent did not meet these criteria, he or she was eliminated from the data analysis. The Organization was given regional categories and a URL link. The Organization then randomly selected 9,000 e-mail addresses (the maximum number the researchers could afford) and sent the URL link along with a cover letter introducing the study. The Organization has indicated that its past experience with blast e-mails results in an average open rate of up to $10 \%$, or in this case with approximately 9,000 e-mails sent, it was estimated that no more than 900 would be opened by the e-mail recipients. According to their results, nearly $10 \%$ or 896 e-mails were opened. To understand why respondents may not have opened the first e-mail and to inspire more responses, after five weeks a follow-up e-mail was sent by the Organization. The majority stated they typically fail to complete surveys due to a general unwillingness to participate in any unsolicited email study.

These results are similar to studies where the survey was designed to select a large sample from a professional sampling agency. ${ }^{3,25,26}$ This sample size (332) was determined to be sufficient in terms of the precision of results ensuring sufficient respondents and indicating respondent characteristics were an accurate representation of the general American population with respect to gender and age. 


\section{Measures}

\section{Wine regions}

The survey employed a preference ranking of ten selected wine appellations and regions of larger and well-known wine producing countries. ${ }^{2}$ The respective appellations were selected from major production areas worldwide and for the United States in particular, appellations that were located where the sample population was located and to consider the perception of local brand image. The regions familiarity was assessed on levels of difficulty by 12 wine experts with the results showing an even spread between easy, moderate and hard levels of difficulty of recognition.

\section{Regional differences}

The respondents were grouped according to the following regional designations established by the United States Census Bureau: ${ }^{27}$ New England, Mid-Atlantic, East N Central, West N Central, South Atlantic, East S Central, West S Central, Mountain, and Pacific. The investigation of regional differences suggests that attitudes, values, and beliefs have historical and cultural roots, and these roots are specific to distinctive regions of the United States. ${ }^{27,28}$

\section{Drivers of preferences}

The PERVAL item scale, as modified by Orth et al from Sweeney and Soutar, was employed for measuring wine region benefits sought by consumers. ${ }^{2,17}$ This study did not assess the items dealing with the Humane Benefit that Orth et al added as their results were not significant. ${ }^{2}$ Accordingly, only 22 items were used in this study and were measured using a seven-point bipolar scale ranging from $1=$ strongly disagree to $7=$ strongly agree. An example of a value dimension is "My favorite wine offers value for the money".

\section{Results}

There were 332 clean and useable questionnaires completed for analyses. Forty-six percent of the respondents were male and 54\% were female. Respondents had high levels of education with $59 \%$ of the sample having earned at least a four-year college degree. Thirty-three percent of the respondents had annual household income of less than $\$ 60,000$, while $15 \%$ had incomes over $\$ 120,000$. The average age of respondents was 44 years and they reported an average of 20 years consuming wine. Overall, the socio-demographic background of the respondents (middle-aged, educated, with higher incomes) mirrored the profile of wine consumers and was similar to data collected in a survey conducted by Barber. ${ }^{24,25}$
Forty-three percent of the respondents were Baby Boomers, 31\% were Millennial and 24\% were Generation X. Years of consumption averaged four years for Millennial, 15 years for Generation X and 31 years for Baby Boomers. The average number of bottles $(750 \mathrm{ml})$ purchased per respondent was 15 per month at a cost of $\$ 318$, or $\$ 23$ per bottle. Those living in the District of Columbia spent the most per bottle (\$32) while those living in Colorado spent the least per bottle (\$16). Fourteen percent of the respondents were from California, $8 \%$ from Massachusetts, 10\% from Maryland, 18\% each from Texas and New Mexico, and 15\% from Virginia. Table 1 shows the consumer preferences as indicated by mean ratings.

Within the sample, Napa Valley, California is the most preferred wine region and Ribera Del Duero, Spain is the least preferred wine origin. Interestingly, those respondents living in Illinois $(M=3.2)$ and Massachusetts $(m=3.2)$, preferred Napa Valley, California wines more than those respondents living in California. Moreover, 93\% of those living in Illinois purchased wines from Napa Valley, California, but only $48 \%$ of those from California purchased wines from their own wine region, Napa Valley.

Respondents were asked to select the country/state of origin from a set of wine appellations. While $87 \%$ of respondents correctly identified the state of origin (California) of Napa Valley, only $18 \%$ correctly identified the state of origin (Texas) of Bell Mountain. Surprisingly, only $81 \%$ of those living in California correctly identified the location of Napa Valley as their own wine producing area and only $18 \%$ of those living in Texas correctly identified Texas's Bell Mountain wine region.

\section{Drivers of preferences}

Following work performed by Orth et al the 22 items assessing the importance of perceived benefits were divided into five separate categories: "Price and value benefit", "Functional benefit", "Environmental benefit", "Social benefit", and "Emotional benefit". ${ }^{2}$ Because the item scale was previously tested in other studies ${ }^{2}$ using exploratory and confirmatory analyses and the reliability and validity assessments were strong, an exploratory factor analysis was not performed for this current study.

A confirmatory factor model using the maximum likelihood technique was estimated via AMOS (release 7.0/SPSS 15.0). After the unidimensionality check, reliabilities were examined using Cronbach's alphas, item reliabilities, composite reliabilities, and average variance extracted (AVE) to assess the internal consistency of multiple 
Table I Respondents wine purchase and consumption $(\mathrm{n}=332)$

\begin{tabular}{|c|c|c|c|c|c|c|c|c|c|c|}
\hline & Overall & CA & CO & IL & MA & MD & $\mathbf{N M}$ & $\mathbf{T X}$ & $\mathbf{V A}$ & WDC \\
\hline $\begin{array}{l}\text { Bottles per month } \\
(750 \mathrm{ml})\end{array}$ & 15 & 14 & 19 & 14 & 13 & 13 & 16 & 12 & 17 & 15 \\
\hline $\begin{array}{l}\text { Total spending on } \\
\text { wine per month }\end{array}$ & $\$ 318.5$ & $\$ 263.9$ & $\$ 362.6$ & $\$ 2 \mid 4.6$ & $\$ 253.5$ & $\$ 289.5$ & $\$ 297.7$ & $\$ 275.3$ & $\$ 495.2$ & $\$ 415.0$ \\
\hline $\begin{array}{l}\text { Average price per } \\
\text { bottle (US\$) }\end{array}$ & \multicolumn{9}{|c|}{ bottle (US\$) } & $\$ 32.0$ \\
\hline \multicolumn{11}{|l|}{ Location of respondents } \\
\hline Survey total & 332 & 46 & 27 & 21 & 28 & 36 & 58 & 59 & 50 & 7 \\
\hline$\%$ of survey respondents & & $13.9 \%$ & $8.1 \%$ & $6.3 \%$ & $8.4 \%$ & $10.8 \%$ & $17.5 \%$ & $17.8 \%$ & $15.1 \%$ & $2.1 \%$ \\
\hline \multicolumn{11}{|l|}{ Age and years of consumption } \\
\hline Average age (years) & 44 & 37 & 38 & 36 & 48 & 40 & 40 & 44 & 44 & 37 \\
\hline $\begin{array}{l}\text { Average years consuming } \\
\text { wine (overall) }\end{array}$ & 20 & 18 & 25 & 25 & 27 & 23 & 25 & 21 & 16 & 24 \\
\hline \multicolumn{11}{|c|}{ Percentage of respondents that purchased wine from these regions } \\
\hline Bell mountain, Texas & $8 \%$ & $3 \%$ & $4 \%$ & $14 \%$ & $12 \%$ & $3 \%$ & $5 \%$ & $14 \%$ & $9 \%$ & $33 \% * *$ \\
\hline Burgundy, France & $30 \%$ & $32 \%$ & $17 \%$ & $57 \%$ & $32 \%$ & $41 \%$ & $29 \%$ & $37 \%$ & $16 \%$ & $33 \%$ \\
\hline Chianti, Italy & $68 \%$ & $53 \%$ & $49 \%$ & $59 \%$ & $79 \%$ & $82 \%$ & $78 \%$ & $68 \%$ & $84 \%$ & $90 \%$ \\
\hline Curico valley, Chile & $4 \%$ & $10 \%$ & $4 \%$ & $7 \%$ & $6 \%$ & $3 \%$ & $2 \%$ & $2 \%$ & $8 \%$ & $2 \%$ \\
\hline Loire valley, France & $16 \%$ & $23 \%$ & $4 \%$ & $43 \%$ & $15 \%$ & $10 \%$ & $10 \%$ & $27 \%$ & $7 \%$ & $67 \%$ \\
\hline Napa valley, CA & $52 \%$ & $48 \%$ & $59 \%$ & $93 \%$ & $59 \%$ & $38 \%$ & $60 \%$ & $55 \%$ & $28 \%$ & $19 \%$ \\
\hline New South Wales, Australia & $49 \%$ & $46 \%$ & $57 \%$ & $49 \%$ & $69 \%$ & $50 \%$ & $42 \%$ & $58 \%$ & $69 \%$ & $71 \%$ \\
\hline Ribera del Duero, Spain & $20 \%$ & $10 \%$ & $7 \%$ & $21 \%$ & $39 \%$ & $7 \%$ & $27 \%$ & $4 \%$ & $32 \%$ & $29 \%$ \\
\hline Russian river valley, CA & $9 \%$ & $16 \%$ & $7 \%$ & $4 \%$ & $9 \%$ & $10 \%$ & $2 \%$ & $12 \%$ & $5 \%$ & $20 \%$ \\
\hline Shenandoah valley, VA & I I\% & $3 \%$ & $13 \%$ & $7 \%$ & $15 \%$ & $7 \%$ & $20 \%$ & $4 \%$ & $15 \%$ & $5 \%$ \\
\hline \multicolumn{11}{|l|}{ Wine region preference*** } \\
\hline Napa valley, CA & 3.5 & 3.4 & 3.9 & 3.2 & 3.2 & 3.6 & 3.9 & 3.5 & 3.4 & 2.6 \\
\hline Burgundy, France & 3.9 & 4.2 & 3.7 & 4.9 & 3.8 & 4.0 & 3.8 & 3.7 & 3.9 & 5.0 \\
\hline Loire valley, France & 4.4 & 3.9 & 4.6 & 4.9 & 4.3 & 4.3 & 4.7 & 4.0 & 4.7 & 4.1 \\
\hline Bell mountain, Texas & 5.5 & 5.8 & 5.4 & 6.4 & 5.4 & 4.7 & 5.6 & 5.0 & 5.8 & 6.0 \\
\hline Shenandoah valley, VA & 5.5 & 5.5 & 6.0 & 6.6 & 5.9 & 5.9 & 4.9 & 5.6 & 5.6 & 6.9 \\
\hline New South Wales, Australia & 5.6 & 5.8 & 6.8 & 6.8 & 6.2 & 6.5 & 6.8 & 5.6 & 5.8 & 6.3 \\
\hline Curico valley, Chile & 5.7 & 5.4 & 5.5 & 6.4 & 6.2 & 5.3 & 6.2 & 6.4 & 6.0 & 5.6 \\
\hline Russian river valley, CA & 5.9 & 5.8 & 5.8 & 5.9 & 6.2 & 6.8 & 6.2 & 6.3 & 5.5 & 6.0 \\
\hline Chianti, Italy & 6.1 & 5.9 & 5.4 & 5.3 & 5.1 & 4.7 & 5.8 & 5.6 & 6.0 & 6.9 \\
\hline Ribera del Duero, Spain & 6.2 & 6.2 & 5.8 & 5.3 & 6.0 & 5.5 & 5.9 & 5.7 & 4.5 & 4.8 \\
\hline \multicolumn{11}{|c|}{ Percentage of respondents correctly identifying wine region location } \\
\hline Bell mountain, Texas & $18 \%$ & $23 \%$ & $26 \%$ & $21 \%$ & $20 \%$ & $14 \%$ & $12 \%$ & $18 \%$ & $19 \%$ & $0 \%$ \\
\hline Burgundy, France & $56 \%$ & $55 \%$ & $65 \%$ & $79 \%$ & $62 \%$ & $59 \%$ & $52 \%$ & $59 \%$ & $40 \%$ & $67 \%$ \\
\hline Chianti, Italy & $77 \%$ & $79 \%$ & $86 \%$ & $84 \%$ & $79 \%$ & $67 \%$ & $75 \%$ & $58 \%$ & $90 \%$ & $85 \%$ \\
\hline Curico valley, Chile & $19 \%$ & $23 \%$ & $26 \%$ & $7 \%$ & $29 \%$ & $10 \%$ & $12 \%$ & $8 \%$ & $37 \%$ & $10 \%$ \\
\hline Loire valley, France & $48 \%$ & $45 \%$ & $70 \%$ & $57 \%$ & $44 \%$ & $45 \%$ & $52 \%$ & $55 \%$ & $33 \%$ & $33 \%$ \\
\hline Napa valley, CA & $87 \%$ & $81 \%$ & $96 \%$ & $100 \%$ & $94 \%$ & $76 \%$ & $91 \%$ & $86 \%$ & $85 \%$ & $83 \%$ \\
\hline New South Wales, Australia & $45 \%$ & $44 \%$ & $42 \%$ & $55 \%$ & $69 \%$ & $49 \%$ & $38 \%$ & $54 \%$ & $45 \%$ & $47 \%$ \\
\hline Ribera del Duero, Spain & $38 \%$ & $32 \%$ & $39 \%$ & $50 \%$ & $38 \%$ & $35 \%$ & $21 \%$ & $43 \%$ & $54 \%$ & $10 \%$ \\
\hline Russian river valley, CA & $27 \%$ & $32 \%$ & $39 \%$ & $43 \%$ & $29 \%$ & $38 \%$ & $7 \%$ & $27 \%$ & $26 \%$ & $0 \%$ \\
\hline Shenandoah valley, VA & $28 \%$ & $29 \%$ & $35 \%$ & $50 \%$ & $32 \%$ & $21 \%$ & $31 \%$ & $27 \%$ & $21 \%$ & $0 \%$ \\
\hline
\end{tabular}

Note: **Will not add up to total sample as some respondents have purchased from more than one location. ***Scale from I = most preferred to $9=$ least preferred. Abbreviations: CA, California; CO, Colorado; IL, Illinois; MA, Massachusetts; MD, Maryland; NM, New Mexico; TX, Texas; VA, Virginia; and WDC, Washington D.C.

indicators for each. ${ }^{29,30,31-33}$ This analysis used the 15 items (Table 2) to verify the factor structure in the proposed scale. ${ }^{28,29}$ A number of widely used goodness-of-fit statistics consistently indicated that the confirmatory factor model satisfactorily reflected a good fit to the data (NFI $=0.92$; $\mathrm{TLI}=0.95 ; \mathrm{CFI}=0.96$; $\mathrm{RMSEA}=0.061$ ).
According to the confirmatory factor analysis, the measures suggested the indicators shared only a single primary construct and were loaded as expected with minimal cross-loadings. ${ }^{34}$ As illustrated in Table 2, Cronbach's alpha estimates, ranging from 0.79-0.90, were acceptable and the standardized factor loadings, ranging from $0.75-0.95$, met the minimum criterion of $0.40 .{ }^{33}$ 
Table 2 Results for equity model $(n=332)$

\begin{tabular}{|c|c|}
\hline & $\begin{array}{l}\text { Confirmatory } \\
\text { factor analysis }\end{array}$ \\
\hline Factor statement (My favorite wine . . . . . . . ) & Factor loadings \\
\hline \multicolumn{2}{|l|}{ Price/value benefit $(\alpha=0.90)$} \\
\hline$\ldots$ is a good product for the price & 0.951 \\
\hline$\ldots$ offers value for money & 0.856 \\
\hline$\ldots$ is very economical & 0.801 \\
\hline \multicolumn{2}{|l|}{ Variance explained } \\
\hline \multicolumn{2}{|l|}{ Functional quality benefit $(\alpha=0.87)$} \\
\hline ... has an acceptable standard of quality & 0.852 \\
\hline$\ldots$ is well made & 0.814 \\
\hline$\ldots$ has consistent quality & 0.774 \\
\hline \multicolumn{2}{|l|}{ Variance explained } \\
\hline \multicolumn{2}{|l|}{ Environmental benefit $(\alpha=0.84)$} \\
\hline $\begin{array}{l}\ldots \text { is produced in an environmentally friendly } \\
\text { manner }\end{array}$ & 0.797 \\
\hline$\ldots$ is made without polluting the environment & 0.748 \\
\hline \multicolumn{2}{|l|}{ Variance explained } \\
\hline \multicolumn{2}{|l|}{ Social benefit $(\alpha=0.82)$} \\
\hline ... makes a good impression on other people & 0.911 \\
\hline ... improves the way I am perceived by others & 0.862 \\
\hline ... helps me feel acceptable & 0.828 \\
\hline \multicolumn{2}{|l|}{ Variance explained } \\
\hline \multicolumn{2}{|l|}{ Emotional benefit $(\alpha=0.79)$} \\
\hline ... makes me feel good & 0.884 \\
\hline ... would give me pleasure & 0.836 \\
\hline ... evokes thoughts of happiness & 0.805 \\
\hline$\ldots$ is one that makes me feel relaxed & 0.792 \\
\hline Total variance explained & \\
\hline
\end{tabular}

The revised model was accepted for subsequent use of the benefit constructs functional, price/value, social, emotional, and environmental. Ratings on the items were then averaged to generate mean scores for the six dimensions.

\section{Dimensions of wine region equity and consumer preferences}

To test Hypothesis One, "Wine preferences for varied subwine regions differ significantly with respect to the benefits consumers seek regarding the five dimensions of wine region equity", a hierarchical stepwise multiple regression analysis was used. Hierarchical multiple regression is similar to stepwise regression, however in this case, the researcher determines the order of entry of the variables. For each wine region, the hierarchical regression entered the regions equity values (quality, price, social, emotion, environmental) into the equation starting with quality, followed by price, social, emotion and finally environmental). The Durbin-Watson Test for serial correlation was performed. For testing whether the assumption of independent errors is defensible, this test measures if adjacent residuals are correlated (an assumption of regression). According to Field, the test statistic can vary between 0 and 4, with a value of 2 suggesting the residuals are uncorrelated. The results of this test ranged from 1.98-2.11, thus there does not appear to be an issue with assumption of independent errors. F-tests were used to compute the significance of each added variable to the explanation reflected in $\mathrm{R}$-square. This hierarchical procedure is an alternative to comparing betas for purposes of assessing the importance of the independents. The results of the hypothesis testing, listed in Table 3, show a number of significant relationships between consumer preference for a wine appellation and benefits sought. Because the preference variable with a lower score represents a high preference, smaller values indicate higher preferences. The "nominal" relationship between brand preferences and benefits sought is reversed with positive (negative) coefficients indicating negative (positive) effect. The results overall offer support for Hypothesis One providing insights into what dimensions of wine region equity motivate consumer preferences. Consumers associate higher quality preferences for wine from Burgundy, France, while a price focus leads to higher preferences for wines from New South Wales, Australia and Curico Valley, Chile. Other origins are preferred due to a perception of offering

Table 3 Equity dimensions and small wine region preferences $(n=332)$

\begin{tabular}{|c|c|c|c|c|c|c|c|c|}
\hline \multicolumn{9}{|l|}{ Motivation $^{a}$} \\
\hline Origin & Quality & Price & Social & Emotion & Environmental & $\mathbf{R}_{\text {adj. }}^{2}$ & $\mathbf{F}$ & Significance \\
\hline Bell mountain, Texas & & & & & $-0.255^{* *}$ & 0.18 & 10.17 & 0.002 \\
\hline Burgundy, France & $-0.4 \mathrm{I} I *$ & $0.246 * *$ & & & & 0.48 & 12.49 & 0.003 \\
\hline Chianti, Italy & $0.227^{* *}$ & & $0.465^{*}$ & & & 0.42 & 9.12 & 0.002 \\
\hline Curico valley, Chile & & $-0.313 * *$ & & & $-0.336 * *$ & 0.25 & 6.78 & 0.013 \\
\hline Loire valley, France & & & $-0.129 * *$ & & & 0.03 & 4.07 & 0.032 \\
\hline Napa valley, CA & $-0.398 * *$ & $0.222 * *$ & $-0.38 I^{* *}$ & & $0.417^{*}$ & 0.51 & 14.89 & 0.001 \\
\hline New South Wales, Australia & & $-0.419 *$ & & $-0.5 \mathrm{II} *$ & & 0.63 & 11.52 & 0.001 \\
\hline Ribera del Duero, Spain & & $0.260^{* *}$ & & & & 0.19 & 7.20 & 0.021 \\
\hline Russian river valley, CA & & & $0.288^{* *}$ & & & 0.22 & 6.98 & 0.011 \\
\hline Shenandoah valley, VA & $0.106 * * *$ & & & & & 0.05 & 5.33 & 0.023 \\
\hline
\end{tabular}

Note: Strength and direction of coefficients indicated by $(+-)$. $* P<0.05 ; * * P<0.01$; $* * * P<0.000$; ${ }^{*}$ Represents standardized beta coefficient. 
social value (Napa Valley, California and Loire, France) or environmental value (Bell Mountain, Texas).

The coefficients showed a significant relationship exists between the benefits consumers seek and origin preferences, indicating that, for example, consumers who value the quality, price, or social dimensions, avoid wines originating in Chianti, Italy or Ribera del Duero, Spain. On the other hand, those consumers valuing the price and emotional dimensions will favor wine from New South Wales, Australia.

Hypothesis Two, "Consumer demographics of gender and age differ significantly with respect to the benefits sought in the dimension of wine region equity", was supported as shown in Table 4. Interestingly, there were significant differences between males and females, with females valuing emotional $(\mathrm{M}=5.5)$ benefits significantly more than males $(\mathrm{M}=4.3), P<0.01$, while males valuing the social benefits $(\mathrm{M}=5.8)$ significantly more than females $(\mathrm{M}=4.1), P<0.00$. Interestingly, both males and females valued price and quality the same. These differences were not surprising because research has found that males are more concerned with social acceptance than females. ${ }^{19,20,22}$ For generation, there were differences between the two cohorts. For example, Millennial generation valued price $(M=5.3)$ significantly more than Generation $X(M=4.6)$, $P<0.01$, while quality $(\mathrm{M}=5.4)$ was valued significantly more than the Millennial generation $(\mathrm{M}=4.6), P<0.00$.

\section{Conclusion and implications}

Over the last three decades, brand equity has received its share of attention in marketing journals and occasionally in wine research and hospitality journals. However, this does not limit the usefulness or importance of understanding wine branding, but rather exemplifies the need for further research.

The relationships between consumer preferences for subwine regions and the desired regional equity benefits were examined, culminating with the identification of several significant associations that management should consider when creating regional brands, selecting target segment and preparing market communication strategies. Consideration of the dimensions of sub-wine region equity identified as motivators of consumer preferences is critical to marketers in designing location-based brands through the communication of selected price, quality, social, emotional, and environmental benefits. Not all wine regions will benefit from promoting them themselves given the current image. For example, Johnson and Bruwer suggested that Alameda is the California county and region that contains the sub-region Livermore Valley, and its image is one of urban congestion. Developing a clear image can be difficult not only because of other-than-wine images but also due to the sheer proliferation of wine regions. ${ }^{11}$

Therefore, knowing how consumer segments support a specific wine sub-region reinforces the need for appropriate target market activities that lend themselves to identification of consumer segments, with information on how these segments react to competing wine regions crucial to market positioning. For example, certain personality traits are associated with masculinity and femininity, with masculinity typically associated with assertiveness, independence, and rationality, while femininity is associated with relational and interdependent aspects such as considerateness, sensitivity, responsibility, and caring. Even products take on a gender association as in wine which is still considered more closely aligned with females. ${ }^{19}$ This concept is supported by Hypothesis Two. For marketers to tap into these unique gender differences and possibly more important for wine producers, is the creation of promotional material directed at attracting males as a potential wine consuming group and thereby creating regional brand loyalty and expanding the overall wine market. This could be accomplished by creating a "masculine" image for wine where males and females are shown in a social situation enjoying wine and food. The same issues exist when considering generational differences. Millennial view price and social as the two key regional equity dimensions and advertising can be directed

Table 4 Wine region equity dimensions $(n=332)$

\begin{tabular}{|c|c|c|c|c|c|c|}
\hline \multicolumn{7}{|l|}{ Demographic' $^{\prime}$} \\
\hline & Male & Female & $P$ & Millennial generation & Generation X & $P$ \\
\hline Price & 4.8 & 4.9 & 0.12 & $5.3^{\mathrm{a}}$ & $4.6^{b}$ & 0.01 \\
\hline Quality & 5.1 & 5.0 & 0.23 & $4.6^{\mathrm{b}}$ & $5.4^{\mathrm{a}}$ & 0.00 \\
\hline Emotional & $4.3^{\mathrm{b}}$ & $5.5^{\mathrm{a}}$ & 0.01 & 4.7 & 4.8 & 0.003 \\
\hline Social & $5.8^{\mathrm{a}}$ & $4.1^{\mathrm{b}}$ & 0.00 & $5.4^{\mathrm{a}}$ & $4.1^{\mathrm{b}}$ & 0.02 \\
\hline Environmental & $4.5^{\mathrm{b}}$ & $5.4^{\mathrm{a}}$ & 0.00 & 4.5 & 4.4 & 0.19 \\
\hline
\end{tabular}

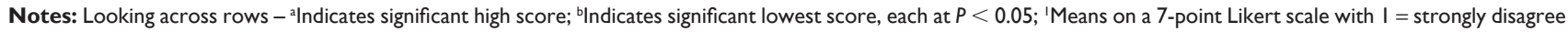
and $7=$ strongly agree. 
to this group through the use of social networking sites such as FaceBook or MySpace, with well placed advertisements linking these two dimensions together.

\section{Disclosure}

The authors report no conflicts of interest in this work.

\section{References}

1. Grewal DL, Michael ED. Marketing. New York, NY; McGraw-Hil Companies Inc; 2008.

2. Orth UR, Wolf MM, Dodd TH. Dimensions of wine region equity and their impact on consumer preferences. The Journal of Product and Brand Management. 2005;14(2/3):88-97.

3. Wilcox JB, Laverie, Debbie A, et al. Facets of brand equity and brand survival: a longitudinal examination. International Journal of Wine Marketing. 2008:20(3):202-214.

4. Kotler P, Gertner D. Country as brand, product and beyond: A place marketing and brand management perspective. Brand Management. 2002;9(4/5):249-261.

5. Mowle J, Merrilees B. A functional and symbolic perspective to branding Australian SME wineries. Journal of Product and Brand Management. 2005;14(4):220-227.

6. Lockshin L, Spawton AL. Using involvement and brand equity to develop a wine tourism strategy. International Journal of Wine Marketing. 2001;13(1):72-81.

7. Nowak LI, Washburn JH. Building brand equity: Consumer reactions to proactive environmental policies by the winery. International Journal of Wine Marketing. 2002;14(3);5-19.

8. Reid M. Building strong brands through the management of integrated marketing communications, International Journal of Wine Marketing. 2002;14(3):37-52.

9. Aaker DA. Managing Brand Equity: Capitalizing on the Value of a Brand Name. New York, NY: The Free Press; 1991.

10. Orth UR. Consumer personality and other factors in situational brand choice variation Brand Management. 2005;13(2):115-133.

11. Bhat S, Reddy SK. 'Symbolic and functional positioning of brands. Journal of Consumer Marketing. 1998;15(1):32-43.

12. Orth UR, Firbasova Z. The role of consumer ethnocentrism in food product evaluation. Agribusiness. 2003;19(1):137-153.

13. LaRoche M, Papadopoulos N, Heslop L, Bergeron J. Effects of subcultural differences on country and product evaluations. Journal of Consumer Behaviour. 2003;2(3):232-237.

14. Baiabanis G, Diamantopoulos A. Domestic country bias, country of origin effect, and consumer ethnocentrism. Academy of Marketing Science Journal. 2004;32(1):80-91.

15. Pharr J. Synthesizing country-of-origin research from the last decade: Is the concept still salient in an era of global brands? Journal of Marketing. 2005;34-45.

16. Verlegh PW, Steenkamp JM. A review and meta-analysis of country-oforigin research. Journal of Economic Psychology. 1999;20(5):521-46.
17. Sweeney J, Soutar G. Consumer perceived value: The development of a multiple item scale. Journal of Retailing. 2001;77(2):203.

18. Vazquez R, del Rio AB, Iglesias V. Consumer-based brand equity: development and validation of a measurement instrument. Journal of Marketing Management. 2002;18(1/2):27-48.

19. Barber N, Almanza B, Donovan J. Motivational factors of gender, income and age on selecting a bottle of wine. International Journal of Wine Marketing. 2006;18(3);218-232.

20. Keller KL. Conceptualizing, measuring, and managing customer-based brand equity. Journal of Marketing. 1993;57(1):1-22.

21. Mitchell VW, Walsh G. Gender differences in German consumer decision making styles. Journal of Consumer Behaviour. 2004;3(4):331-346.

22. Hall J, Shaw M, Lascheit J, Robertson N (2000). Gender differences in a modified perceived value construct for intangible products. ANZMAC 2000 Visionary Marketing for the 21st Century: Facing the Challenge. Accessed 11 February 2010.

23. Wine Market Council 2006. Wine market council consumer tracking study - 2006. Available from: http://www.winemarketcouncil.com/ Accessed 5 March 2010.

24. Barber N. How self-confidence and knowledge effects the sources of information selected during purchase situations. Published dissertation, Lubbock, TX: Texas Tech University; 2008.

25. Motto Kryla Fisher L. US Wine Demographics Report. St. Helena, CA; The Wine Business Center, 25;2000.

26. Diamantopoulosa A, Schlegelmilchb B, Sinkovicsd B, Bohlen G. Can socio-demographics still play a role in profiling green consumers? A review of the evidence and an empirical investigation. Journal of Business Research. 2003;56:465-480.

27. US Census. 2008. United States Department of Commerce, Regional Designations. Available from: http://www.census.gov/Retrieved July 8, 2009.

28. Guagnano GA, Markee N. Regional differences in the sociodemographic. Determinants of environmental concern. Population and Environment. 1995;17(2):135-149.

29. Hair J, Anderson R, Tatham R, Black W. Multivariate Data Analysis. (5th ed). Upper Saddle River, NJ: Prentice Hall; 1998.

30. Ryu K, Jang S. The effect of environmental perceptions on behavioral intentions through emotions: The case of upscale restaurants. Journal of Hospitality and Tourism Research. 2007;3(1):56-72.

31. Gerbing D, Anderson J. Monte Carlo evaluations of goodness-of-fit indices for structural equation models. In: Bollen KA, and Long JS (Ed), Testing structural equation models. Newbury Park, CA: Sage Publications. 1993:40-65.

32. Green S, Salkind N. Using SPSS for Windows and Macintosh: Analyzing and understanding data. (4th Ed). Upper Saddle Ridge, NJ: Pearson/ Prentice Hall. 2005.

33. Kline R. Principles and practice of structural equation modeling. (2nd ed). (pp. 12-13 sample size, (pp. 47-95 structural equation modeling and model specifications). NY: Guilford Press. 2004.

34. Tabachnick B, Fidell L, (2001). Using Multivariate Statistics. Structural Equation Modeling. Boston, MA: Allyn and Bacon; 2001:653-771.
International Journal of Wine Research

\section{Publish your work in this journal}

The International Journal of Wine Research is an international, peer-reviewed open-access, online journal focusing on all scientific aspects of wine, including: vine growing; wine elaboration; human interaction with wine; and health aspects of wine. The journal provides an open access platform for the reporting

\section{Dovepress}

of evidence based studies on these topics. The manuscript management system is completely online and includes a very quick and fair peer-review system, which is all easy to use. Visit http://www.dovepress.com/testimonials.php to read real quotes from some of our published authors 